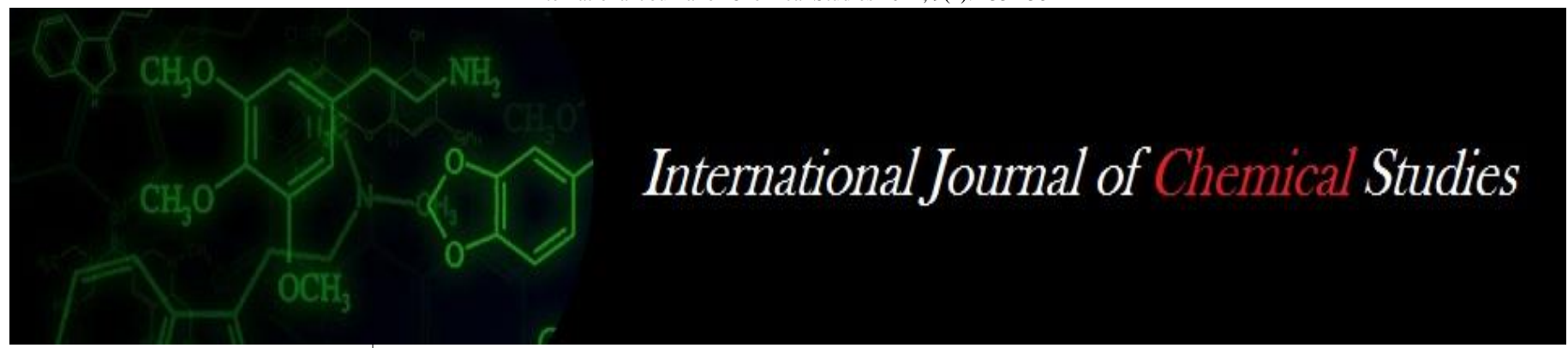

P-ISSN: 2349-8528

E-ISSN: 2321-4902

www.chemijournal.com

IJCS 2021; 9(1): 133-138

(C) 2021 IJCS

Received: 04-11-2020

Accepted: 17-12-2020

Lakra LP

Department of Agricultural

Processing and Food

Engineering, Faculty of

Agricultural Engineering, IGKV,

Raipur, Chhattisgarh, India

\section{S Patel}

Department of Agricultural

Processing and Food

Engineering, Faculty of

Agricultural Engineering, IGKV,

Raipur, Chhattisgarh, India
Corresponding Author:

Lakra LP

Department of Agricultural

Processing and Food

Engineering, Faculty of

Agricultural Engineering, IGKV

Raipur, Chhattisgarh, India

\section{To study the Physico-chemical properties of Lathyrus sativus}

\section{Lakra LP and S Patel}

DOI: https://doi.org/10.22271/chemi.2021.v9.i1b.11220

\begin{abstract}
The physical and mechanical properties are important for developing primary processing machinery. The geometric properties such as size and shape, equivalent diameter, sphericity, surface area, volume are the important physical properties used in developing machineries for separation and cleaning. The present study was undertaken to the axial dimension of Lathyrus sativus (Var. Mahateora). The four levels of moisture content were taken at 7.78, 9.54, 11.61 and 14.86 percent (dry basis).The average value of length; width and thickness were varied from 5.20 to $5.24 \mathrm{~mm}, 4.29$ to $4.70 \mathrm{~mm}$ and 3.51 to $4.05 \mathrm{~mm}$ respectively. While the bulk density and true density was decreased from 848.84 to $794.44 \mathrm{~kg} / \mathrm{m}^{3}$, 1218.32 to $1130.50 \mathrm{~kg} / \mathrm{m}^{3}$. The surface area by equivalent diameter, surface area by axial dimension and porosity was found to be 55.85 to $67.75 \mathrm{~mm}^{2}, 50.83$ to $62.27 \mathrm{~mm}^{2}$ and 30.84 to 31.46 percent. The angle of repose and coefficient of friction was varied in the range of 22.41 to $29.02^{\circ}$ and plywood plate, galvanized iron plate and rubber plate surface were found to be varied 0.41 to $0.55,0.45$ to $0.58,0.63$ to 0.72 respectively. The proximate composition of Lathyrus sativus split dhal was observed the protein, fat, total ash, carbohydrate and fiber content as 22 percent, 2.3 percent, 2.90 percent, 60.00 percent, 3.94 percent respectively.
\end{abstract}

Keywords: Lathyrus sativus, physico-chemical properties, axial dimension, (Var. Mahateora)

\section{Introduction}

Pulses are the most prominent and economic source of vegetative protein and cheap source of body-building protein as well. The Lathyrus sativus are one of the most commonly using pulses all over the world. Lathyrus (Lathyrus sativus L.) belong to the Fabaceae family. From the morphological point of view of Lathyrus sativus is much-branched, herbaceous annual crop with a well -developed taproot system. In India the Lathyrus sativus is known as Lakhori, Teora and Khesari, and in Ethiopia it is also known as grass pea and chickling pea and chickling vetch. It contributes in overcoming the illnesses from many chronic diseases. Pulses are the low glycemic index foods having high fiber content. Lathyrus is a good source of polyphenol and antioxidant protein. India is the largest producer of this very important crop and rightly has highest consumer. In India the highest production of pulses was estimated to the tune of 23 million tonnes in the year 2016-2017. In addition to this it is one of the essential protein sources for nearly 80 percentage people of all age groups in their daily diet. Lathyrus seed contains the anti - nutritional properties such as phytic acid, tannins, and $\beta$-ODAP ( $\beta$ Oxalyl diaminopropionic acid). It has been seen from the literature survey, that excess consumption of Lathyrus causes the paralysis of the limb and arises many other health issues.

\section{Materials and Methods}

\section{Sample preparation}

The Lathyrus sativus used in the study was obtained from the local market of Raipur (C.G.). All the Foreign matters, impurities are cleaned and removed manually using sieves, bamboo winnowing basket and tray. In order to attain the desired moisture $(7 \%, 9 \%, 11 \%, 14 \%)$ levels for the study, taken the (260g) Lathyrus seeds and adding a calculated amount of distilled water. The Lathyrus sample was well mixed and conditioned after that the sample were tightly packed in the plastic. The conditioned samples were kept in a refrigerator set at $\left(5 \pm 1{ }^{\circ} \mathrm{C}\right)$ for 7 days for to perform the uniformly moisture distribution. 


\section{Determination of physical properties \\ Equivalent diameter $\left(D_{e}\right)$}

To determine the average size of seeds, for measuring equivalent diameter of Lathyrus seeds, four samples measuring $260 \mathrm{gm}$ each were taken from the conditioned sample at different level of moisture content viz. 7\%, 9\%, $11 \%, 14 \%$ respectively. From each sample, 50 randomly selected Lathyrus seeds were measured in the three mutually perpendicular directions the length, width, and thickness. The following formula was used to calculate the equivalent diameter Dhake et al. (2017); Ghamari et al. (2014); Kenghe et al. $(2011)^{[9,12,20]}$.

$$
\mathrm{D}_{\mathrm{e}}=(\mathrm{LWT})^{1 / 3}
$$

\section{Sphericity $(\varnothing)$}

Sphericity denotes the roundness of the object. Initially 4 samples measuring $260 \mathrm{gm}$ each were taken from the conditioned sample at different level of moisture content viz. $7 \%, 9 \%, 11 \%$, and $14 \%$ respectively. Then 50 Lathyrus seeds were selected randomly and linear measurement was made in three mutually perpendicular directions. The sphericity was calculated by the formula. (Zewdu et al. 2008) ${ }^{[44]}$.

$\emptyset=\frac{(\mathrm{LWT})^{1 / 3}}{\mathrm{~L}}$

\section{Gravimetric properties}

\section{Thousand seed mass $\left(M_{t}\right)$}

For the thousand seeds mass, Randomly 100 Lathyrus seeds were taken from the $(260 \mathrm{~g})$ of Lathyrus seeds sample and weight measurement was done using the weighing balance. This way 10 lots of each 100 Lathyrus seeds were prepared. Thousand seed mass $\left(\mathrm{M}_{\mathrm{t}}\right)$ was calculated by the following formula (Chouhan, 2018).

$\mathrm{M}_{\mathrm{t}}=\frac{1000 \times \mathrm{W}_{\mathrm{p}}}{\mathrm{n}_{\mathrm{s}}}$

\section{Bulk density $\left(\rho_{\mathrm{b}}\right)$}

The bulk density of Lathyrus seeds was determined using the standard test weight procedure (Baryeh, 2001). The bulk density was calculated from the mass of Lathyrus seeds divided by the volume of the container. Lathyrus seeds were freely filled up to the top level in the beaker of $250 \mathrm{ml}$ volume. No additional compaction was given during the process. The Following formula was used for calculating the bulk density of Lathyrus seeds.

Bulk density $\left(\rho_{\mathrm{b}}\right)=\frac{\mathrm{w}}{\mathrm{V}}$

\section{True density}

The ratio of mass of sample to the true volume is termed as true density of the sample. The true density was determined using the toluene displacement method. The sample of $10 \mathrm{~g}$ Lathyrus seeds were immersed in graduated measuring cylinder in which $20 \mathrm{ml}$ toluene was filled and then the amount of displaced toluene was recorded. According to (Singh and Goswami, 1996) [30] the true density was calculated using following formula:

True density, $\left(\rho_{\mathrm{t}}\right)=\frac{\mathrm{w}}{\mathrm{V}}$

Where,

$\rho_{\mathrm{t}}=$ True density of seeds, $\mathrm{Kg} / \mathrm{m}^{3}$
$\mathrm{W}=$ Weight of seed, $\mathrm{Kg}$

$\mathrm{V}=$ Volume of seed, $\mathrm{m}^{3}$

\section{Porosity}

It is the percentage of volume of voids in the test sample at given moisture content. It was calculated as the ratio of the difference in the true and bulk density to the true density.

$\varepsilon=\frac{\rho_{\mathrm{t}-\rho \mathrm{b}}}{\rho_{\mathrm{t}}} \times 100$

\section{Where}

$\rho_{\mathrm{b}}=$ Bulk density, $\mathrm{Kg} / \mathrm{m}^{3}$

$\rho_{\mathrm{t}}=$ True or particle grain density, $\mathrm{Kg} / \mathrm{m}^{3}$

\section{Frictional properties}

\section{Angle of repose}

The angle of repose is the angle between the base and the slope of the cone formed by the vertical fall of the granular material on a horizontal plane. The angle of repose of the Lathyrus seeds was calculated from the height and the diameter of the naturally formed heap of the seeds on a particular plate which was measured by measuring scale. According to Zendu et al., (2008) ${ }^{[44]}$ the following formula using calculating the angle of repose.

$\theta=\tan ^{-1} \frac{2 \mathrm{H}}{\mathrm{B}}$

\section{Where}

$\mathrm{H}=$ Height of heap

$\mathrm{B}=$ Diameter of wooden plate

\section{Coefficient of friction $(\boldsymbol{\mu})$}

The coefficient of kinetic friction was determined with respect to the three different surfaces viz; sheets plywood plates, galvanized iron plate and rubber plate. The Lathyrus seeds were fed in a square steel container. The square steel container was connected to a hanging weight carrier by means of a rope (thin thread), which is passed over a frictionless pulley at the one end of the table. The container was placed on the surface sheet and weight $(200 \mathrm{~g}, 100 \mathrm{~g}, 50 \mathrm{~g}, 20 \mathrm{~g}, 10 \mathrm{~g}$, $5 \mathrm{~g}$ ) were added to the hanging carrier gradually until container just started to slide on the surface. According to Zewdu et al. (2008) ${ }^{[44]}$ the formula was used to determine the coefficient of friction $(\mu)$.

$\mu=\mathrm{F} / \mathrm{R}$

\section{Where}

$\mu=$ Coefficient of friction

$\mathrm{F}=$ Force of limiting friction

$\mathrm{R}=$ Normal reaction

\section{Results and Discussions \\ Grain dimension}

The determined physical properties of the moisture content of the Lathyrus seeds were found to be varied from 7.78 to 14.86 percent $(\mathrm{db})$ while the length, width, and thickness was varied from ranged 5.20 to $5.24 \mathrm{~mm}, 4.29$ to $4.70 \mathrm{~mm}$ and 3.51 to $4.05 \mathrm{~mm}$ respectively. Similarly reported by Dhake et al. (2017); Ghamari et al. (2014); Kenghe et al. $(2011)^{[9,12,20]}$

\section{Sphericity}

The sphericity of Lathyrus seeds were varied from 0.811 to 0.884 percent. 


\section{Equivalent diameter}

Equivalent diameter of Lathyrus seeds were varied from 4.20 to $4.62 \mathrm{~mm}$ with respect to moisture content range from 7.78 to 14.86 percent.

\section{Thousand seed mass}

The thousand seeds weights of Lathyrus were increased varied from $79.97 \mathrm{~g}$ to $83.50 \mathrm{~g}$.

\section{Bulk density}

The bulk density and true density of Lathyrus seeds was decreased from 848.84 to $794.44 \mathrm{~kg} / \mathrm{m}^{3}, 1218.32$ to 1130.50 $\mathrm{kg} / \mathrm{m}^{3}$

\section{Surface area}

The surface area of Lathyrus seeds were calculated by two different methods. The surfaces are by equivalent diameter and surface area by axial dimension. The surface area by equivalent diameter was found to be 55.85 to $67.75 \mathrm{~mm}^{2}$ and the surface area by axial dimension was found to be 50.83 to $62.27 \mathrm{~mm}^{2}$.

\section{Porosity}

The porosity of Lathyrus seeds was varied in the range of 30.84 to 31.46 percent.

\section{Angle of repose}

The angle of repose of Lathyrus seed were varied in the range of 22.41 to $29.02^{\circ}$ with respect to moisture content range of 7.78 to 14.86 percent $(\mathrm{db})$.

\section{Coefficient of friction}

The coefficient of friction of Lathyrus seeds for plywood plate, galvanized iron plate and rubber plate surface were found to be varied in the range of 0.41 to $0.55,0.45$ to 0.58 , 0.63 to 0.72 .

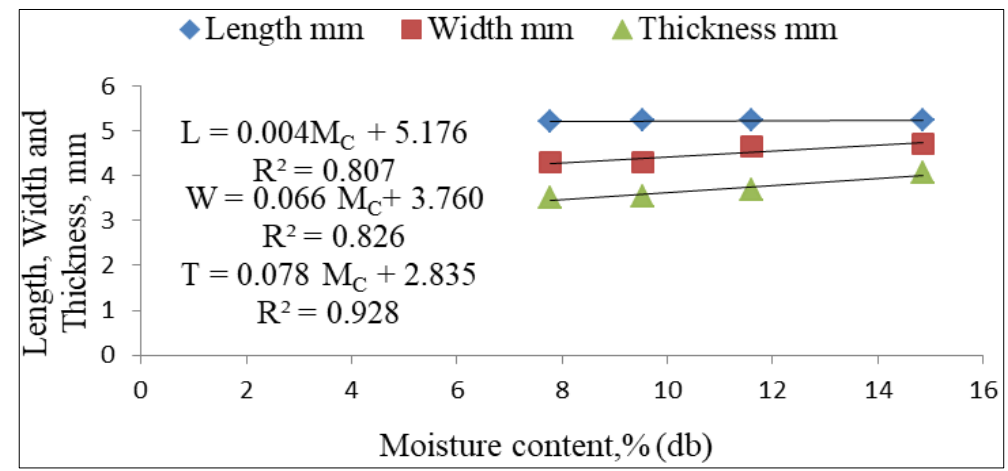

Fig 1: Effect of moisture content on axial dimension of Lathyrus seeds

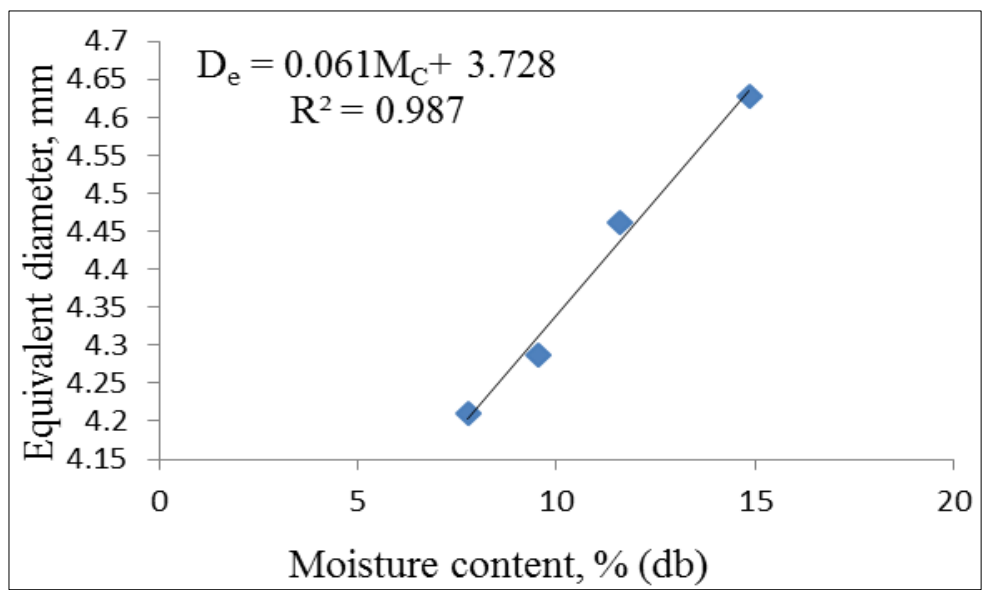

Fig 2: Effect of equivalent diameter of Lathyrus seeds with respect to moisture

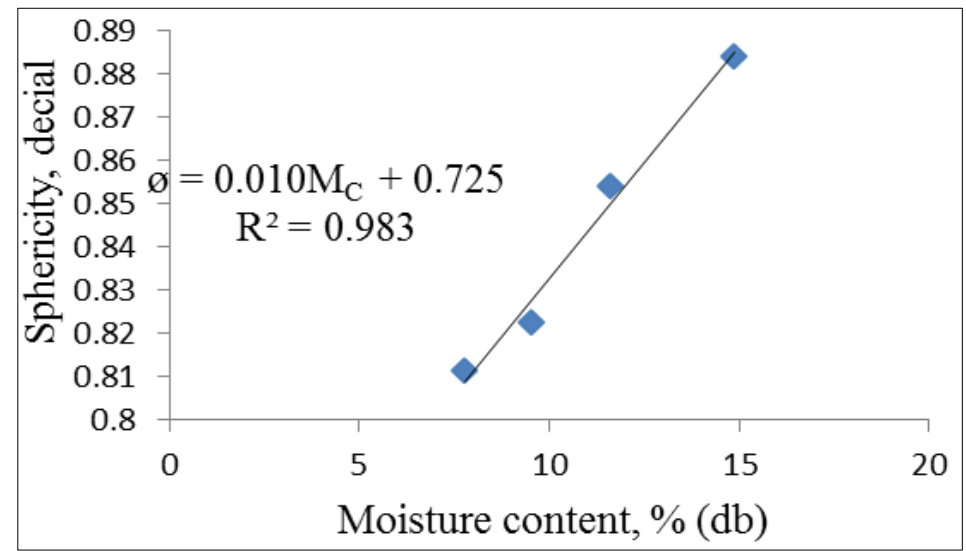

Fig 3: Effect of moisture content on sphericity of Lathyrus seeds 


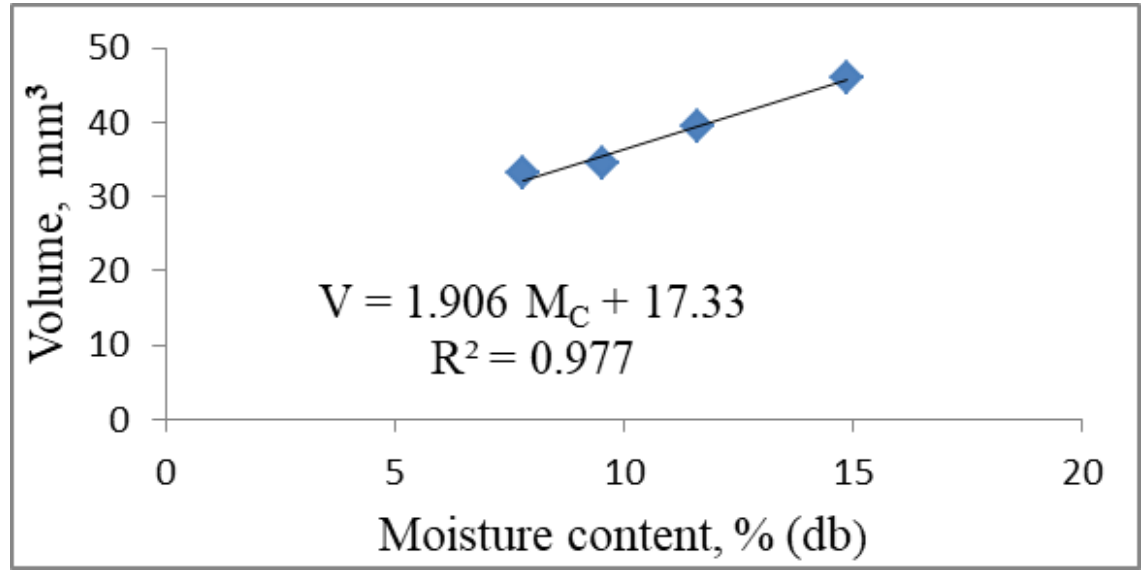

Fig 4: Effect of moisture content on volume of Lathyrus seeds

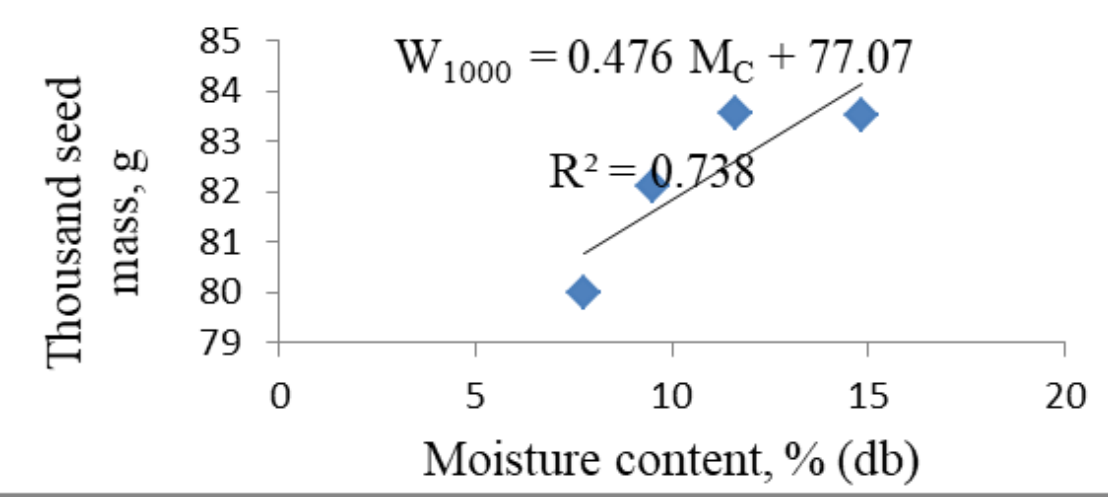

Fig 5: Effect of moisture content on thousand seeds weight of Lathyrus seeds

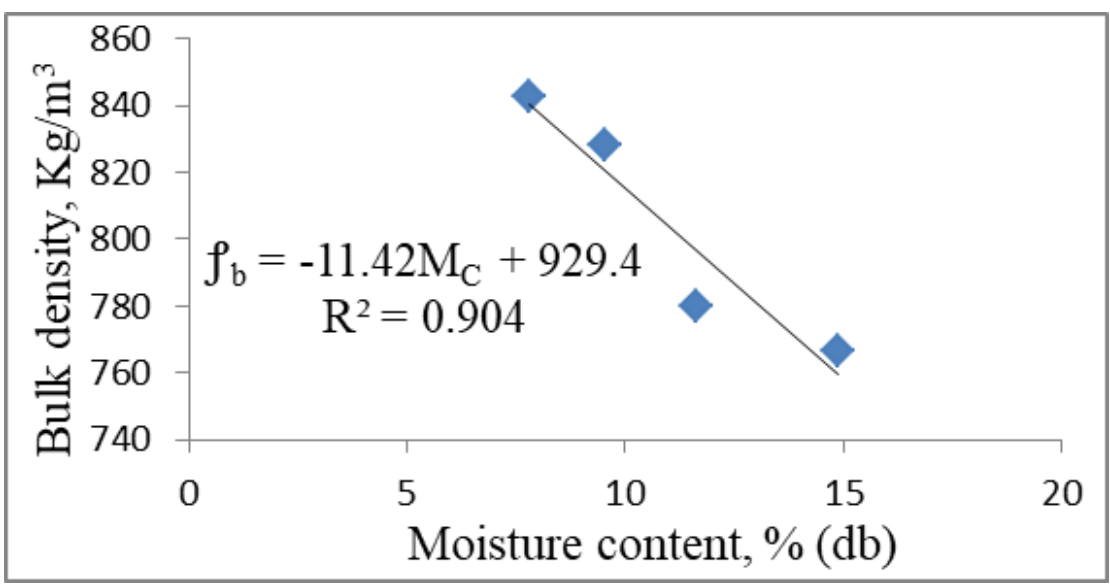

Fig 6: Effect of moisture content on bulk density of Lathyrus seeds

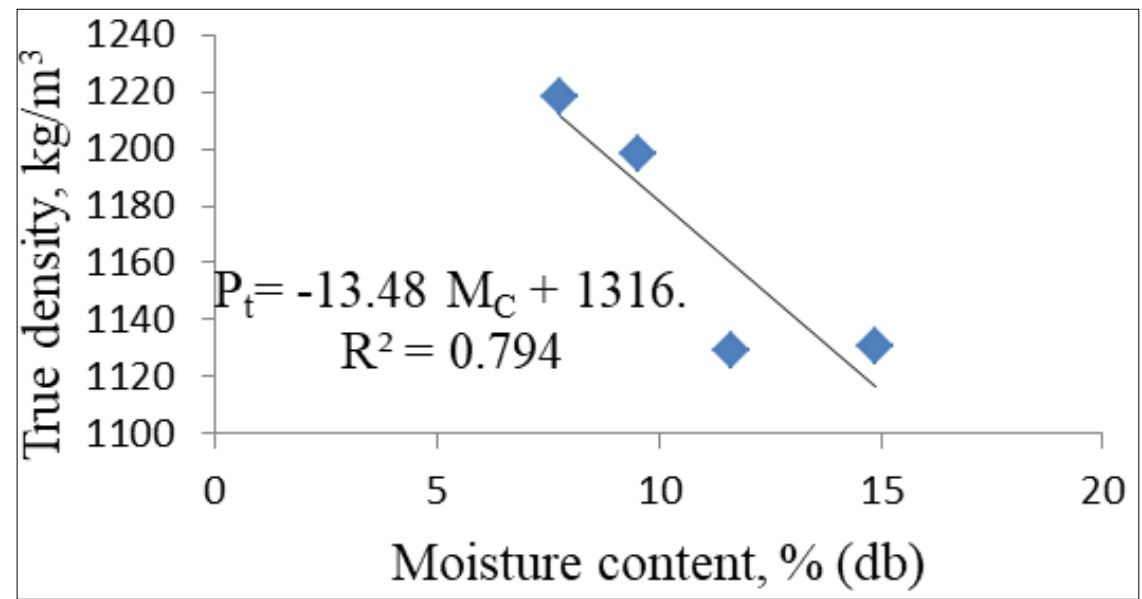

Fig 7: Effect of moisture content on true density of Lathyrus seeds 


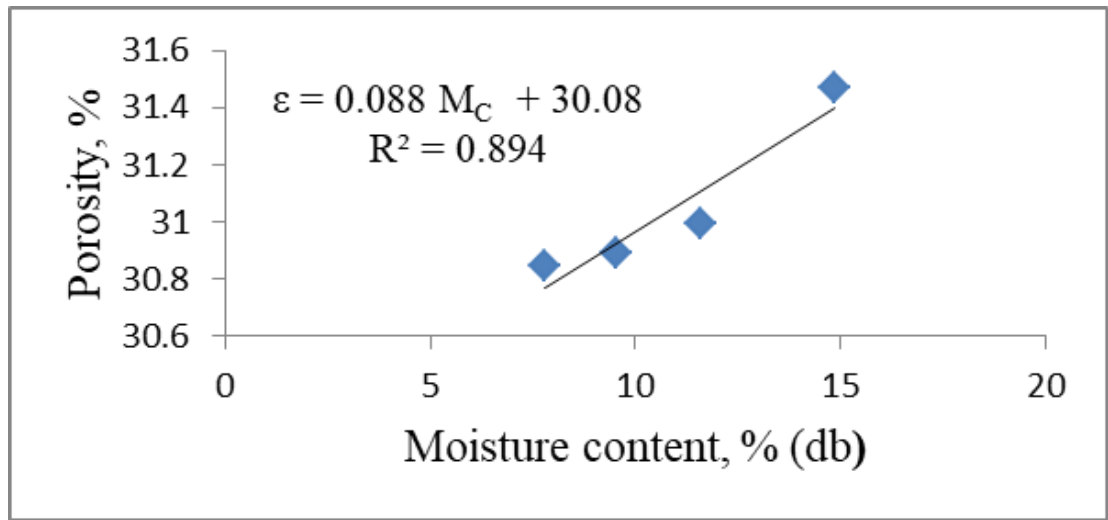

Fig 8: Effect of moisture content on porosity of Lathyrus seed

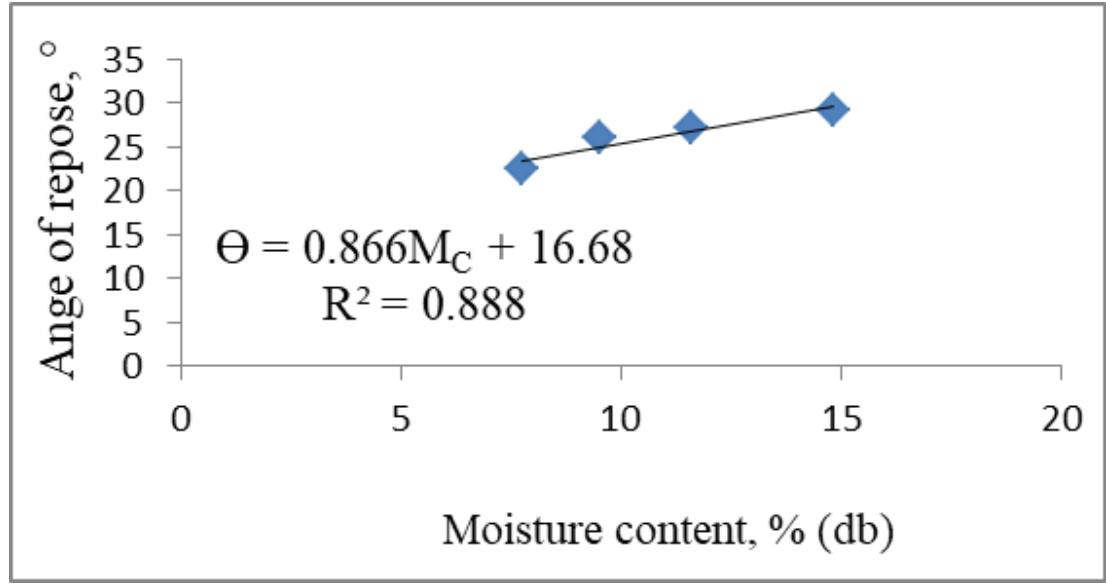

Fig 9: Effect of moisture content on angle of repose of Lathyrus seeds

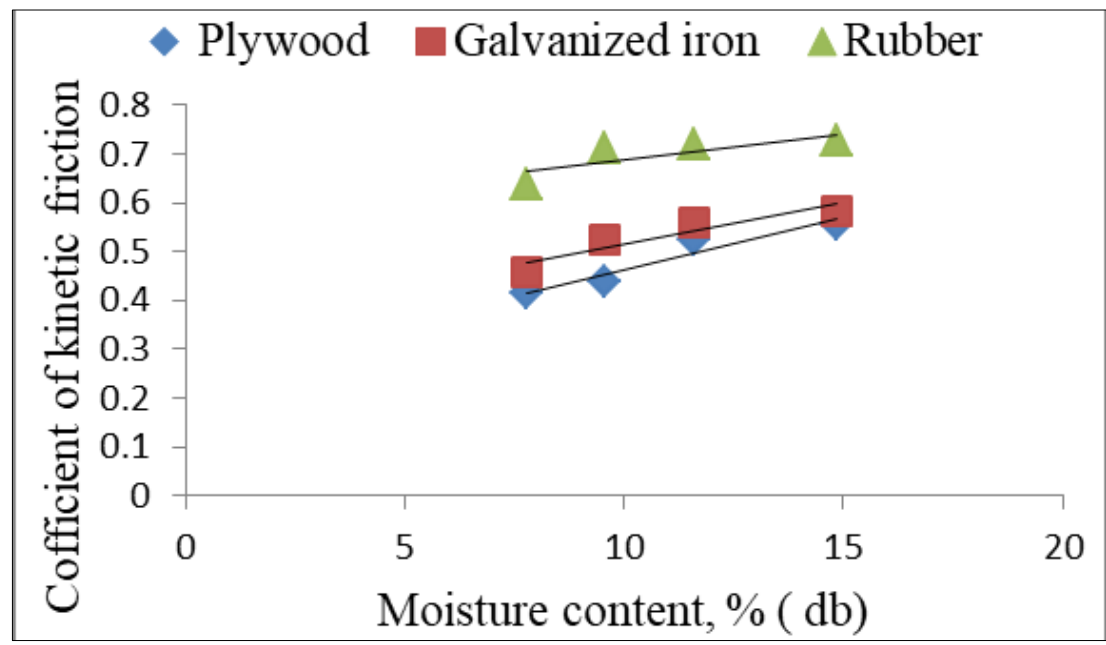

Fig 10: Effect of moisture content on coefficient of kinetic friction of Lathyrus seeds

\section{Conclusion}

From the results of experimental studies it can be concluded that physical properties including axial dimension, equivalent diameter, sphericity, volume, thousand seed weight, surface area, porosity, angle of repose, coefficient of friction were increasing with respect to moisture.

\section{References}

1. Akalu G, Johansson G, Nair BM. Effect of processing on the content of $\beta$-N-oxalyl- $\alpha, \beta$-diamino propionic acid $(\beta$ ODAP) in grass pea (Lathyrus sativus) seeds 1998.

2. Amin MN, Hossain MA, Roy KC. Effects of moisture content on some physical properties of lentil seeds. Journal of Food Engineering 2004;65(1):83-87.
3. Aruna T, Devindra S. Nutritional and anti-nutritional characteristics of two verities of red gram (Cajanus Cajan) seeds 2016;6(9):2250-3153.

4. AOAC. Official methods of analysis, 17th Edition. Association of Official Analytical Chemists, Arlington, Virginia 2000;6:2250-3153.

5. Bakhtiari MR, Ahmad D, Othman J, Ismail N. Physical and mechanical properties of kenaf seed applied engineering in agriculture 2011;27(2):263-268.

6. Bamgboye IA, Adebayo SE. Seed moisture dependent on physical and mechanical properties of Jatropha curcas 2012.

7. Baran MF, Durgut MR, Aktaş T, Ülger P, Kayışoğlu B. Determination of some physical properties of rapeseed 2016. 
8. Chowdhury MMI, Sarker RI, Bala BK, Hossain MA. Physical properties of gram as a function of moisture content. International Journal of Food Properties 2001;4(2):297-310.

9. Dhake KP, Gajabe MH, Burbade RG. Moisture dependent physical properties of Bengal gram seeds (Cicer arientimum L.) 2017.

10. Dutta SK, Nema VK, Bhardwaj RK. Physical properties of gram. Journal of Agricultural Engineering Research 1988;39(4):259-268.

11. Ganjloo A, Bimakr M, Zarringhalami S, Safaryan JM, Ghorbani M. Moisture-dependent physical properties of green peas (Pisum sativum L.). International Food Research Journal 2018;25(3):1246-1252.s

12. Ghamari S, Mohammadi K, Khanahmadzadeh A, Goli H. Evaluation the some physical properties of chickpea seeds in Kurdistan region of Iran. International Journal of Agriculture and Forestry 2014;4(3A):4-7.

13. Ghodki BM, Goswami TK. Effect of moisture on physical and mechanical properties of cassia. Cogent Food \& Agriculture 2016,2(1).

14. Habibullah AM, Shah HU. Proximate and mineral composition of mung bean. Sarhad J Agric 2007;23(2):463-466.

15. Hailu D, Abera S, Teka TA, Box PO, Jimma E. Effects of Processing on Nutritional Composition and AntiNutritional Factors of Grass pea (Lathyrus Sativus L): A. A review 2015;36:61-71.

16. Jain RK, Bal S. Properties of pearl millet. Journal of agricultural engineering research 1997;66(2):85-91.

17. Jouki M, Khazaei N. Some physical properties of rice seed (Oryza sativa). Research journal of applied sciences, engineering and technology 2012;4(13):1846-1849.

18. Jukanti AK, Gaur PM, Gowda CLL, Chibbar RN. Nutritional quality and health benefits of chickpea (Cicer arietinum L.): a review. British Journal of Nutrition 2012.

19. Karababa E, Coşkuner Y. Moisture dependent physical properties of dry sweet corn kernels. International Journal of Food Properties 2007,10(3).

20. Kenghe RN, Nimkar PM, Shirkole SS. Moisture dependent physical properties of Lathyrus. Journal of food science and technology 2013;50(5):856-867.

21. Nimesh A, Sharanagat VS. Effect of moisture content on engineering properties of chickpea seed. Agricultural Engineering Today 2016,40(1).

22. Poomsa-ad N, Wiset L, Duangkhamchan W. Effect of moisture content on physical and aerodynamic properties of sorghum. Journal of Medical and Bioengineering 2014,3(3).

23. Ramakrishna V, Rani PJ, Rao PR. Anti-nutritional factors during germination in Indian bean (Dolichos lablab L.) seeds. World Journal of Dairy \& Food Sciences 2006;1(1):06-11.

24. Ramezani PN. Induction of mutation inL grasspea Lathyrus sativus Linn through gamma radiation and ethyl methanesulphonate 2015.

25. Razavi SMA, Yeganehzad S, Sadeghi A. Moisture dependent physical properties of canola seeds. J. Agric. Sci. Technol 2009;11(3):309-322.

26. Sangani VP, Davara PR. Moisture dependent physical properties of pigeon pea grains. International Journal of Postharvest Technology and Innovation 2013,3(1).

27. Seifi MR, Alimardani R. Comparison of moisturedependent physical and mechanical properties of two varieties of corn (Sc 704 and Dc 370). Australian Journal of Agricultural Engineering 2010,1(5).

28. Sharon MEM, Abirami CK, Alagusundaram K, RPS, JA. Moisture Dependent Physical Properties of Black gram. Agricultural Engineering International: CIGR Journal 2015,17(1).

29. Singh U, Voraputhaporn W, Rao PV, Jambunathan R. Physico-chemical characteristics of pigeon pea and mung bean starches and their noodle quality. Journal of Food Science 1989;4(5):1293-1297.

30. Singh KK, Goswami TK. Physical properties of cumin seed. Journal of Agricultural Engineering Research 1996;64(2):93-98.

31. Sonawane AV, Rajwade YA, Singh D, Desai S, Rajurkar GB. Moisture dependent physical properties of horse gram. International Agricultural Engineering Journal 2014;23(2):7-14.

32. Srivastava $S$, Khokhar $S$. Effects of processing on the Reduction of $\quad \beta$-ODAP $\quad(\beta-\mathrm{N}-\mathrm{Oxalyl}-\mathrm{L}-2$, 3-diaminopropionic acid) and Anti-Nutrients of Khesari Dhal, Lathyrus sativus. Journal of the Science of Food and Agriculture 1996;71(1):50-58.

33. Taghi Gharibzahedi SM, Mousavi SM, Ghahderijani M., A survey on moisture-dependent physical properties of castor seed (Ricinus communis L.). Australian Journal of Crop Science 2011;5(1):1.

34. Tavakoli M, Tavakoli H, Rajabipour A, Ahmadi H, Gharib-Zahedi SMT. Moisture-dependent physical properties of barley grains. International Journal of Agricultural and Biological Engineering 2010;2(4):84-9

35. Tunde-Akintunde TY, Akintunde BO. Some physical properties of sesame seed. Biosystems Engineering 2004;88(1):127-129.

36. Urga K, Fite A, Kebede B. Nutritional and antinutritional factors of grass pea (Lathyrus sativus) germplasms. Bulletin of the Chemical Society of Ethiopia 1995,9(1).

37. Urga K, Fite A, Kebede B. Nutritional and antinutritional factors of grass pea (Lathyrus sativus) germplasms. Bulletin of the Chemical Society of Ethiopia 1995,9(1).

38. Urga K, Fufa H, Biratu E, Husain A. Evaluation of Lathyrus sativus cultivated in Ethiopia for proximate composition, minerals, $\beta$-ODAP and anti-nutritional components. African Journal of Food, Agriculture, Nutrition and Development 2005,5(1).

39. Woldemedhin AF. Improving the nutritional quality of Lathyrus sativus L. (grass pea) for safer consumption 2008.

40. Yalçın İ, Özarslan C. Physical properties of vetch seed. Biosystems Engineering 2004;88(4):507-512

41. Yan ZY, Spencer PS, Li ZX, Liang YM, Wang YF, Wang CY et al. Lathyrus sativus (grass pea) and its neurotoxin ODAP. Phytochemistry 2006;67(2):107-121.

42. Yerra S, Putta S, Kilari EK. The role of Food Processing Techniques in the detoxification of ODAP IN Lathyrus sativus. International Journal of Information Research and Review 2016,3(8).

43. Zareiforoush H, Komarizadeh MH, Alizadeh MR. Effect of moisture content on some physical properties of paddy grains. Research Journal of Applied Sciences, Engineering and Technology 2009,1(3).

44. Zewdu AD, Solomon WK. Moisture-dependent physical properties of grass pea (Lathyrus sativus L.) seeds. Agricultural Engineering International: CIGR Journal 2008. 